\title{
The Ninth Circle: Who and What Do We Trust In Today's World?
}

\author{
Michael Ashby
}

Published online: 24 February 2017

(C) Journal of Bioethical Inquiry Pty Ltd. 2017

Keywords Publictrust Philosophy of science - Ethics of science $\cdot$ Bioethics $\cdot$ Modern fiction $\cdot$ Communication

The issue starts with a dialectic between Shaw (2017) and Penders (2017) about the nature of authorship: the "vagueness" of a laissez-faire approach as opposed to a more rigorous "nowhere to hide" set of rules to ensure that nobody gets a free ride (English common law v continental codes is the legal example of the fundamental tension at play here). This at a time when the "currency" of authorship is very real: the metrics of the academic career have a definite value for promotion, tenure and funding. As every sphere of life is measured, categorized, and then regulated, does it make a better world, and how do we all preserve our sanity in the process that greater procedural rigor demands of us, and does it takes us where we want to go (assuming that the destination is agreed in the first place)?

Leigh Rich (2017) has set the scene (below) for the trust symposium, which has a particular focus on public trust in the domain of expert knowledge. In her introductory editorial essay, Rich sets the scene with a literary take on the issues by discussing the interface

\footnotetext{
M. Ashby $(\bowtie)$

Palliative Care Service, Royal Hobart Hospital, Tasmanian Health Service, and School of Medicine, Faculty of Health Sciences, University of Tasmania, 1st Floor, Peacock Building, Repatriation Centre, 90 Davey Street, Hobart, TAS 7000, Australia

e-mail: michael.ashby@ths.tas.gov.au
}

between fact and fiction in the modern novel. She refers extensively to the work of Karl Ove Knausgård whose multi-volume "novel" based on his own life (the provocatively titled My Struggle, that may lay some claim to be in the tradition of Rousseau's Confessions [France 1987]): is a lacerating exposition of the inner life of a man laying bare his behavior (good, but often also bad), his unconscious, and thereby also in a tangential way, his spiritual world view (Knausgård 2013). In a Freudian way both writers reveal their true instincts and selftalk in which the writer-reader covenant is challenged throughout to ask: was it really like this, what would the other characters say if they could give their version of events, stripped of the writer's account: super ego, ego, and id? This is true for the writer, but is it true to you the reader, indeed can we trust the text? Perhaps the point of this "fiction" is that it is just that and should be seen as neither true nor false but a work of art that reveals the human condition: warts and all; fact and fantasy all mixed up in one.

Dante reserves the deepest place in hell in the "Inferno" for those who betray trust. Trust is at the heart of human relationships in every way, and is the bedrock of all bioethics and all caring relationships. It is also the cornerstone of political functioning, although frequently (and maybe more frequently now in democracies that espouse higher collective principles?) honoured in the breach. Tell a big lie that is popular enough and you will get away with it? The sceptic tradition is one that exhorts us to be personally discerning about what we read and watch, to take nothing for granted; but how can any society function if it cannot make assumptions of 
veracity in its political, scientific, and cultural spheres? Trust has to be "earned" it is often said. None of us can be experts in everything, so we do rely on what we know or believe to be the expertise of others. In postwar England, for instance, scientists were once referred to in collective and reverential terms: "they can do wonderful things these days" - assuming some kind of assumed trust in the inherent goodness of science and progress. However, distrust of science, especially in health and food matters is now rife, as the massive growth in alternative and complementary healthcare shows, people flock in huge numbers to practices that makes sense for them, even if the underlying theories at play have little or no "scientific" basis. Powerful "elites" are under attack, babies flying out with the bath water everywhere, and trust only established where care and individual attention are lined up, and theories that may be baseless are accepted because they tell us something we want to hear and in many cases provide a basis for agency and action that more mainstream ideas do not. Gray (2017) from Wellington, New Zealand, picks up this theme with regard to recent controversies about homeopathy and suggests that a binary approach is unhelpful for patients and argues for a more inclusive way of integrating this practice into healthcare, including a better understanding of placebo responses.

Bouzenita (2017), writing from Oman, gives us a valuable Islamic account of stem cell harvesting, but also provides an accessible overview of Islamic bioethics. In Islam he explains, legal and ethical perspectives are closely overlapped into one religious approach to ethical evaluation of everything, including the subject of the article. This is, of course, a contrast to western bioethics, that situates itself in a theologically neutral, secular, space so that dispositions can be independent of any particular theology.

Bosteels et al. (2017) from Gent, Belgium, interrogates the ever-expanding nature of public health interventions for children, with particular regard to screening for deafness. The bigger question here is: where are the limits of personal (and in this case parental) liberty as society is driven by utilitarian norms to identify defects and disabilities to correct? The pursuit of the perfectibility of the human condition may be an un-interrogated and assumed public interest, that is not without social and political consequences, and at the very least need to be monitored and questioned as these authors do.

Clucas and St Claire (2017) from Bristol, United Kingdom, contribute an empirical study of respectfulness amongst medical students. They conclude that "unconditional" respect can be increased by appropriate interventions. It might be troubling to many that it is necessary to do this for students who have chosen a medical career. It is a challenge for all health educators to inculcate a professional approach to patient care that is respectful but also allows students to process, in a safe and healthy way, the feelings they will inevitably have when they are required to care for people who display behaviours and say things that may, for instance, at times, be rude, discriminatory, or even criminal. To what extent can attitudes be taught, and perhaps more importantly role-modelled? This work also begs the question, with something as inner and personal as respect, of how much comes from the heart, is truly felt and acted out, as opposed to phoney and done only to pass exams and comply with professional standards. How much value do patients and communities place on acted out values and superficial (or even artificial) care, that have no sincere personal basis. Maybe sometimes that's just how it has to be for the fair and effective delivery of healthcare, especially in a pluralist world? Queen Elizabeth I famously observed that she did not have a window into men's souls on religious matters, and so it is for the motivations of ethical behaviour. However, human beings, no less so when they are patients or clients, have a very highly attuned monitoring sense for authenticity, and students need to be aware of this.

Blikshavn, Husum, and Magelssen (2017) from Norway argue that assisted dying should not be made available to people with depression. They dispute the existence of an entity of "treatment-resistant" depression and the admission of hopelessness. In the modern war on depression and suicide, the medical paradigm is dominant and despite all the admissions by mental health professionals that drugs cannot "cure" depression, there seems little place for any understanding of those whose genetic make-up, and personal and social situations fail to respond to multiple attempts at "gold standard" modern multimodal psychiatric treatment. In the understandable and broadly supported common desire to prevent the tragedy of suicide, especially those that result from untreated mental illness, it seems that all suicide is seen as unacceptable and no sense of the possibility that for some people it is an understandable, and perhaps ultimately, inevitable, outcome. This is prominently seen in the current debates about assisted suicide. However, it is possible that the question Camus 
poses in the opening paragraphs of The Myth of Sisyphus, is now answered by a medical approach that denies the possibility of the "rational" suicide, and is maybe, dare one say, in some small way also driven by a sense that a person who commits suicide is a threat to the living by devaluing the currency of being alive (Camus and O'Brien 1955)? A now long dead London psychiatry professor once said in a medical student lecture that he was occasionally relieved when he heard that one of his long-term depressed patients had successfully committed suicide, as a final release from misery that he was unable to sustainably relieve. These words seemed at the time to be both pragmatic and kind, but these days he would probably be sacked. Can we ever dare to admit that someone in dire circumstances might be better off dead?

Cooper (2017) from Bonn, Germany, reviews The Biopolitics of Lifestyle by Christopher Mayes. This books employs Foucault's notion of the "dispositif" that looks at the influence of social constructions, and thereby social control or "governability," on individuals, with specific regard to the obesity "epidemic" in western societies, and is described by the reviewer as "confrontational."

Purdy and coauthors (2017) from Sydney, Australia, explore conflicts of interest (COI) with regard to the pharmaceutical industry and medicine. They conclude that present methods are essentially binary, and attempts to eradicate COI are failing as part of a polarized discourse that is stagnant and unhelpful. They conclude that exploration of the profoundly different views about "security and flourishing" at play here needed to be unpacked and better understood as more fruitful way forward.

Richards and Okninski (2017), in their regular "Recent Developments" column about legal events in Australia report and comment on two cases. The first concerns the professional implications of the conduct of research that is outside the traditional professional conduct framework, and shows that research conduct was seen by the relevant Australian Capital Territory tribunal as residing within the clinical sphere and therefore subject the same professional standards. They then return to the Oshin case in Western Australia and point out that the court agreed to palliative care for a boy with an incurable brain tumour but was at pains to point out that this decision was not generalizable, pertaining only to the situation of the child concerned, and his interests only. This is a timely reminder to those of us outside the legal world to be careful about the citation of common law cases with regard to their "generalizability" and hence use and deployment in other cases and ethics debates.

Michael Ashby

Editor in Chief (Content)

\section{Thanks to Our Reviewers and Associate Editors}

In closing, the editorial team at the $J B I$ would like to wish you all well for the forthcoming year. At this time we pause to acknowledge the great debt we owe to a number of colleagues who have left the editorial team over the course of 2016. Catherine Mills (Biopolitics and Critical Bioethics), Sarah Winch (Clinical Ethics), Ainsley Newson (Science and Genetics), and Sarah Breier (Nursing Ethics) have all contributed enormously to the journal over the past few years and we wish them well for the future. Catherine Myser (Global Bioethics) and Peter Omonzejele (Cross-Cultural Bioethics) have also moved on from their Associate Editor positions to take up roles on the International Advisory Board where we hope to continue to draw from their invaluable expertise. And of course we acknowledge the ongoing, immeasurable contributions of our current Associate Editors, Executive Committee, and Editorial Board who continue to work tirelessly to ensure the JBI continues to grow and to fulfil its mission. Joining the editorial team over the past year have been Nikola Stepanov (Clinical Ethics), Kristina Orfali (Women and Children Bioethics and Cross-Cultural Bioethics), Ilana Maymind (Ethics and Faith), Zubin Master (Science and Genetics), Silvia Camporesi (Ethics and Reproduction), and Sunday Pam (Women and Children Bioethics), all of whom we greatly look forward to working with over the coming years.

We would also like to thank our reviewers (below) for their contributions over the last year. It is an often apparently thankless task that has to be added to already full days, by busy people, and makes yet another demand on top of the day job, family, and any leisure time our reviewers dare to give themselves. Our heartfelt thanks to you, without our reviewers, peer review would collapse. Maybe we could start a campaign to get proper international university recognition of journal 
reviewing, however, this would probably just add to the metrics burden for academics and violate the comments made in the first paragraph!

Michael Ashby

Editor in Chief (Content)

and

Bronwen Morrell

Editor in Chief (Production)

Our Reviewers in 2016

Kenneth Robert Abbey

Courtney Page Addison

Christine Aicardi

Lynley Anderson

Warwick Anderson

Roberto Andorno

Mark H. Arnold

Robert Baker

Angela Ballantyne

Leslie Becker

Zara Jean Bending

Shawna Benston

Israel Berger

Johan Christiaan Bester

Andrew Blades

Teresa Blankmeyer Burke

Stella Bolaki

Laura Bothwell

Lynne Bowyer

Kenneth Boyd

Sandra Bradley

Sarah Brand

Iain Brassington

Hillel Braude

Annette Braunack-Mayer

Tommaso Bruni

Janet Buelow

William Bülow

Letitia Helen Burridge

Carlo Caduff

Silvia Camporesi

David Carter

Colleen Cartwright

Giulia Cavaliere
Michael Chapman

Kata Chillag

Salvatore Chirumbolo

Tina Cockburn

Christopher Coenen

Andrew Cooper

Richard Cooper

Andrew Courtwright

Jonathan M Dapaah

Thierry Daboval

Michael David Dahnke

Ben Davies

Arlene Davis

Lorenzo Del Savio

Clare Delany

Justin T. Denholm

Casey Dorman

Charles Douglas

Raluca Dumache

Trish Dunning

Cameron Ellis

Shahram Ahmadi Nasab Emran

Aaron Fellmeth

Scott J. Fitzpatrick

Jessica Flanigan

Neil Francis

Paige Franklin

Lucas França Garcia

Marjolaine Frenette

Enrique Gavilán-Moral

Nader Ghotbi

Kenneth W. Goodman

Kevin James Goodwin

Ben Gray

Matteo Gulino

Jyotsna Gupta

Barbara Hawkins

Carolyn Hayes

Adrian Holme

Samia Hurst

Douglas Hutchinson

David Isaacs

Steven Jackson

Barbara Jericho

Britt Elsa Johnson

L. Syd M. Johnson

Karin Jongsma

Christopher F.C. Jordens

Barry Jubraj 
Jon Jureidini

John Kaplan

Maria Karanikola

Angeliki Kerasidou

Henry Kilham

Emma Kowal

Kate Laver

Michela Lazzarin

Morgan LeFay Holmes

Kimberly Leighton

Phoebe Li

Miles Little

Stefan Litz

Federica Lucivero

Susan MacCallum

Bill Madden

Luca Marelli

Dominique Martin

Paul Howard Mason

Christopher Mayes

Frances A. McCarty

Rosalind McDougall

Marcus McLeod

Karen Meagher

Heidi Mertes

Steven Miles

Eleanor Milligan

Valeria Morabito

Charles Mpofu

Jing-Bao Nie

Holly Louise Northam

Robert Orr

Danielle Paciulli

Susan Palmer

Ron Paterson

Bart Penders

Diane Perpich

Alan Petersen

Leslie Pickering Francis

Hans Pols

Emily Postan

Kay Price

Neil Price

Kasper Raus

Cassandra Rivais

Wendy Rogers

Kathryn Rogers-Carpenter

Christopher James Ryan

Maya Sabatello
Emma Sacks

Roberta Sala

Jennifer Salerno

Priya Satalkar

Peter Saul

Carolin Schurr

Anne Scott

Ian Scott

Kate Seear

Salaam Semaan

Michael Shapiro

Rhonda Shaw

Morven Shearer

Bryan Sisk

Robert Smith

Stephen O. Sodeke

Michael Souter

Merle Spriggs

Trevor Gordon Stammers

Natalie Taylor

Alison K. Thompson

Bernadette Tobin

Yesim Isil Ulman

Alessia Valongo

Floris van den Berg

Andreas Vilhelmsson

Ayo Wahlberg

Paul Walker

Simon Thomas Walker

Narelle Warren

Bruce D. White

Mark Wicclair

Henri Wijsbek

Simon Woods

Lynn Woodward

Tanya Wyatt

Henrik Zetterberg

Li Claire Zhang

Ayuba Ibrahim Zoakah

\section{References}

Blikshavn, T., T.L. Husum, and M. Magelssen. 2017. Four reasons why assisted dying should not be offered for depression. Journal of Bioethical Inquiry 14(1). doi:10.1007/s11673-016-9759-4.

Bosteels, S., M. Vandenbroeck, and G. Van Hove. 2017. Saving deaf children? Screening for hearing loss as a public-interest case. Journal of Bioethical Inquiry 14(1). doi:10.1007 /s11673-016-9752-y. 
Bouzenita, A.I. 2017. "Harvesting" and use of human (embryonic) stem cells: An Islamic evaluation. Journal of Bioethical Inquiry 14(1). doi:10.1007/s11673-016-9757-6.

Camus, A., and J. O'Brien. 1955. The myth of Sisyphus, and other essays. Vintage.

Clucas, C., and L. St. Claire. 2017. How can respectfulness in medical professionals be increased? A complex but important question. Journal of Bioethical Inquiry 14(1). doi:10.1007 /s11673-016-9758-5.

Cooper, A. 2017. Review of The biopolitics of lifestyle: Foucault, ethics and healthy choices by Christopher Mayes. Journal of Bioethical Inquiry 14(1). doi:10.1007/s11673-016-9763-8.

France, P. 1987. Rousseau: Confessions. Cambridge University Press.

Gray, B. 2017. How should we respond to non-dominant healing practices, the example of homeopathy. Journal of Bioethical Inquiry 14(1). doi:10.1007/s11673-016-9760-y.

Knausgård, K.O. 2013. My struggle: Book two: A man in love. Translated by D. Bartlett. New York: Farrar, Straus and Giroux.
Penders, B. 2017. The value of vagueness in the politics of authorship. Journal of Bioethical Inquiry 14(1). Doi: 10.1007/s11673-016-9768-3.

Purdy, S., M. Little, C. Mayes, and W. Lipworth. 2017. Debates about conflict of interest in medicine: Deconstructing a divided discourse. Journal of Bioethical Inquiry 14(1). doi:10.1007/s11673-016-9764-7.

Rich, L. 2017. Prestidigitation vs. public trust: Or how we can learn to change the conversation and prevent powers from "organizing the discontent". Journal of Bioethical Inquiry 14(1). doi:10.1007/s11673-017-9769-x.

Richards, B.J., and M. Okninski. 2017. Considering professional misconduct and best interests of a child (palliative orders). Journal of Bioethical Inquiry 14(1). doi:10.1007/s11673016-9765-6.

Shaw, D. 2017. A response to penders: The value of vagueness in the politics of authorship. Journal of Bioethical Inquiry 14(1). doi:10.1007/s11673-017-9770-4. 